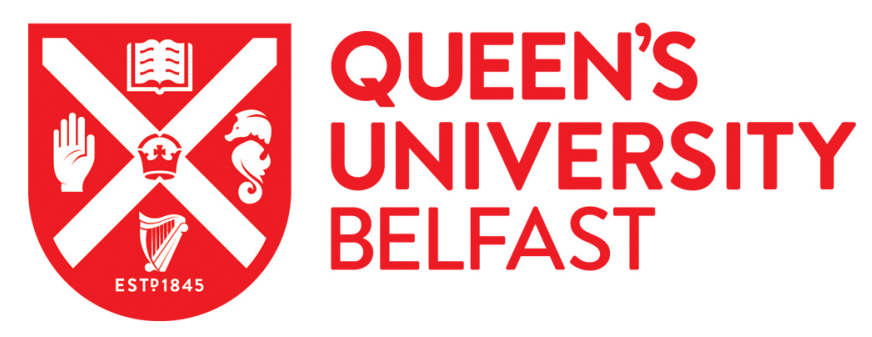

\title{
Constituency Preferences and Assignment to Agriculture Committees
}

Raymond, C. D., \& Holt, J. (2019). Constituency Preferences and Assignment to Agriculture Committees. Parliamentary Affairs, 72(1), 141-161. https://doi.org/10.1093/pa/gsy012

Published in:

Parliamentary Affairs

Document Version:

Peer reviewed version

Queen's University Belfast - Research Portal:

Link to publication record in Queen's University Belfast Research Portal

Publisher rights

Copyright 2018 Oxford University Press. This work is made available online in accordance with the publisher's policies. Please refer to any applicable terms of use of the publisher.

\section{General rights}

Copyright for the publications made accessible via the Queen's University Belfast Research Portal is retained by the author(s) and / or other copyright owners and it is a condition of accessing these publications that users recognise and abide by the legal requirements associated with these rights.

Take down policy

The Research Portal is Queen's institutional repository that provides access to Queen's research output. Every effort has been made to ensure that content in the Research Portal does not infringe any person's rights, or applicable UK laws. If you discover content in the Research Portal that you believe breaches copyright or violates any law, please contact openaccess@qub.ac.uk. 


\title{
CONSTITUENCY PREFERENCES AND ASSIGNMENT TO AGRICULTURE COMMITTEES
}

\begin{abstract}
Summary
With only a handful of exceptions, most research examining the impact of constituency preferences on committee assignments in legislatures outside the United States is comprised of single-case studies. This raises the question whether the impact of constituency preferences on committee assignments seen in previous studies apply cross-nationally. Focusing on committees whose remit includes agricultural affairs - because such committees may be particularly sensitive to constituents' particularistic interests - this study examines the impact of constituency preferences on committee assignments in twenty-nine legislatures. The analysis suggests constituency preferences may impact committee assignments in legislatures around the world, and that this effect varies to only a limited extent according to differences in electoral systems, committee organisation, and the partisan consequences of personal vote-seeking.
\end{abstract}

\section{Key Words}

Agriculture; committee selection; constituency preferences; distributive theory 
Though the body of research examining committee assignments in legislatures outside the US has expanded considerably in recent years, there remains considerable room for the development of truly cross-national explanations. One of the issues holding back the theoretical development of this literature is the fact most studies examining committee assignments have focused on one institution. In addition to preventing us from making comparisons across legislative institutions, focusing on one legislature makes it difficult to determine whether theories of legislative organization apply broadly to committee selection in legislatures around the world, or whether the theories developed in the context of US legislatures only apply under certain conditions in particular legislatures.

One such theory designed to explain committee selection that might be conditional on the context of legislatures is distributive theory. According to distributive theory, representatives seek out committee assignments allowing them to represent their constituents' particularistic interests, which in turn increases representatives' potential to build personal votes and improve their chances of re-election. Though some research examining legislatures outside the US has tested distributive theory (e.g. Ciftci, Forrest, and Tekin, 2008; Fujimura, 2012; Raymond and Holt, 2014, 2017; Yordanova, 2009), the coverage of countries testing the implications of distributive theory for committee selection leaves much to be desired. Moreover, there remains considerable work to be done to examine whether/why the effects of constituency preferences rooted in distributive concerns on committee selection differ across legislatures.

This paper examines the impact of constituency preferences on committee assignments in several legislatures around the world. Specifically, the analysis examines the impact of constituency preferences related to agricultural interests on the assignment of representatives to committees whose remits include agricultural issues. This comparative focus allows for an 
analysis of several factors influencing the degree to which constituency preferences impact committee selection in several legislatures around the world. Because this paper presents the first (to the authors' knowledge) broad, comparative study of committee selection, the results have important consequences for research on committee assignments and the generalizability of distributive effects.

In the next section, we elaborate on distributive theory's predictions regarding committee selection, as well as the competing explanations of committee assignment. Following that, we outline several hypotheses regarding variables that might condition the effects of constituency preferences on committee selection. After that, we discuss the details of our research design before proceeding to a discussion of the results of our empirical analysis. A final section concludes with a discussion of the implications for future research.

\section{Theories of committee selection}

A large body of literature on committee selection in legislatures in the US examines whether constituents' preferences impact representatives' committee assignments. One theory, distributive theory, argues that elected representatives are likely to seek and be assigned to committees that have influence over policies important to members' constituents, especially committees that have influence over policies affecting their constituents' economic interests. Distributive theory argues that representatives are motivated by a desire to win re-election, and committees provide them different opportunities to aid their re-election chances (Mayhew 1974; Shepsle, 1978; Shepsle and Weingast, 1981, 1995).

Committees help members' re-election prospects in several ways. First, committees give members the ability to secure particularistic benefits for their constituents because they allow 
members the opportunity to shape legislation under the committee's jurisdiction and make sure it benefits their constituents. Committees also allow members a way to claim credit for securing public projects in their districts - even when representatives are not responsible for securing the benefit (see Mayhew, 1974, Shepsle, 1978). Committees also allow members the opportunity to take positions (through votes, speeches, and questions at hearings) on issues important to their constituents. Taking positions on issues in committee is important because there are many issues where members do not get the opportunity to take positions for that issue on the floor.

The goal of these behaviours is to develop personal votes, which are votes gained based on representatives' reputations among their constituents (e.g. Cain, Ferejohn, and Fiorina, 1987). Developing personal votes among constituents is important because personal votes increase representatives' chances of winning re-election in close races, which especially important in elections where representatives' party brands (the constituents' view of the party's reputation) are held in poor regard. Because most representatives in most elections want to win re-election to maintain their political careers, and given the need to develop personal votes to maintain their positions in office, distributive theory predicts that representatives will seek appointment to committees that allow them to pursue their constituents' particularistic interests.

In contrast to distributive theory, two other theories predict that legislators seeking to represent their constituents' interests on committees to further their personal ambitions are not likely to be appointed to their desired committees (Martin and Mickler, 2018). One is informational theory, which argues that legislatures are designed to ensure they receive the most accurate information possible in order to produce good policies (Gilligan and Krehbiel, 1990; Krehbiel, 1991). Given that accurate information is necessary to create good policy, legislatures will be unlikely to assign representatives with distinct preferences - especially those seeking to 
represent their constituents' particularistic preferences - to committees with jurisdiction over these policies because such members are more likely to provide the legislature with biased information serving their own interests (as opposed to the interests of the legislature).

A second theory predicting that representatives with distinct preferences will not be successful in their efforts to reach their desired committee is cartel theory (Cox and McCubbins, 1993). Cartel theory acknowledges the incentives facing parties not to promote such committeeseeking behaviour. First, party leaders are averse to appointing representatives with constituencies incentivising personal vote-seeking behaviour because party leaders must protect the party brand, as the collective image of members conveyed by the party label affects the reelection prospects and policy goals of every member of the party. Party leaders will serve as gatekeepers to committees, preventing members with distinct preferences from being selected to their preferred committees lest these members' pursuit of re-election through representation of constituents' distributive interests damage the party brand. Second, cartel theory argues that legislatures are designed to help the ruling party pass its agenda. Committees that are made up of members with preferences different from the party median are a potential threat to the party's ability to pass its agenda. Therefore, parties will not allow committees to be made up of members representing constituencies with particularistic interests that deviate from the interests of the party.

Most empirical analyses of committee selection have focused on American legislatures, though some research studying legislatures outside the US is starting to emerge. Although some studies - including those examining the impact of representatives' ideological positions on committee selection in the US House of Representatives (Krehbiel, 1990; Groseclose, 1994) and state legislatures (Overby and Kazee, 2000; Overby, Kazee, and Prince, 2004; Prince and 
Overby, 2005) - have found little evidence in favour of distributive theory, other research has concluded in favour of distributive theory (Carsey and Rundquist, 1999; Londregan and Snyder, 1994; Weingast and Marshall, 1988). Evidence in favour of distributive theory is particularly evident when examining the impact of constituency preferences on committee selection (Adler, 2000; Adler and Lapinski, 1997; Sprague, 2008), which more directly test predictions associated with distributive theory than variables measuring representatives' personal preferences.

Outside the US, where parties play an even greater role organising and operating legislatures, there may be reason to believe that constituency preferences do not impact committee selection and distributive theory does not apply (as cartel theory would predict). There is evidence, however, that distributive theory applies in the cases in which it has been studied, including Japan (Fujimura, 2012), Denmark (Hansen, 2010), Turkey (Ciftci, Forrest, and Tekin, 2008), and the European Parliament (Yordanova, 2009). Additionally, those studies examining the particular impact of constituency preferences on committee selection have, like their American counterparts, found evidence in keeping with the predictions of distributive theory, at least in the handful of legislatures in which distributive theory has been conceptualised as constituency interests (Raymond and Holt, 2014, 2017; Stratmann and Baur, 2002). Thus, there is reason to believe that constituency preferences may affect selection to committee crossnationally. This leads to our main hypothesis:

H1: Representatives from constituencies with more constituents affected by the actions of a committee are more likely to be selected to committees dealing with their constituents' interests than representatives with fewer such constituents. 
In seeking to expand the focus on constituency preferences affecting committee selection to legislatures around the world, additional work remains to be done examining the impact of institutional, organisational, and other contextual factors that promote or inhibit the representation of constituents' preferences on committees. Do certain contextual factors allow for constituency preferences to impact committee selection in some legislatures and not in others? To this end, the next section outlines several such features and outlines their hypothesized conditional effects on the way in which constituency preferences impact committee selection.

\section{Factors potentially influencing committee selection}

When examining selection to committees in comparative perspective, there are a range of variables that might condition the degree to which constituency preferences influence committee selection. In this study, we focus on the impact of four sets of legislature-level variables: how members of each legislature are elected and the electoral incentives to represent constituency interests; the overlap between the committee's remit and the ministry overseen by the committee; the degree to which the committee's remit is focused specifically on agricultural issues; and the regional/national consequences of constituency preferences and personal vote-seeking for representatives' parties. In this section, we outline hypotheses associated with each type of conditional effect.

Given the development of the literature related to the impact of electoral systems on representatives' behaviour, the most obvious set of variables relate to differences in electoral systems. The key difference emphasised in the literature is between electoral systems creating chances for representatives to develop personal votes and electoral systems limiting the 
possibility of developing personal votes (Carey and Shugart, 1995). Representatives in personal vote systems will be more likely to seek assignment to committees whose jurisdiction affects their constituents' interests because constituents in these systems can/do vote for individuals, and not solely for party lists. Because constituents in personal vote systems can vote for individual candidates, these systems allow and incentivise representatives to develop personal votes that improve their chances of re-election - while electoral systems where constituents vote solely for a party list do not. To attract personal votes that increase their chances of re-election, representatives in legislatures with personal vote systems should be more likely to seek assignment to committees with influence over policies affecting their constituents' economic interests than representatives elected in non-personal vote systems. In line with these arguments, previous research has found that representatives elected under electoral rules incentivizing personal vote seeking are more constituency oriented than those elected under rules that deemphasise individual candidates (André, Freire, and Papp, 2014; Stratmann and Baur, 2002; Heitshusen, Young, and Wood, 2005; André, Depauw, and Martin, 2016b). If representatives elected under electoral rules inhibiting identification of individual representatives are less constituency-oriented, they will be less likely to seek assignment to committees helping them to represent their constituents' preferences. To determine whether personal vote systems increase the impact of constituency preferences on committee selection, we examine a second hypothesis:

H2: The effects of constituency preferences will be stronger in personal vote systems than in party-centric electoral systems.

Another set of variables that might affect the degree to which constituency preferences 
impact committee selection relate to the power and remit of committees. One assumption required for the predictions of distributive theory to hold is that committees are attractive enough for representatives to want to be selected: while some research provides evidence that constituency preferences influence selection to committees, this assumes representatives can use committees meaningfully to claim credit and take positions signalling their positions to constituents. However, previous research shows there is considerable variation in the strength and autonomy of committees, particularly outside the US (André, Depauw, and Martin, 2016a; Mickler, 2017). Therefore, we might expect that the clearer the opportunities for position-taking and credit-claiming, the more likely representatives will seek selection to committees aligning with their constituents' interests, and thus, the stronger the impact of constituency preferences on committee selection.

One factor that might increase the desire of representatives to seek selection to committees is the degree to which committee remits overlap with government ministries. Previous research (e.g. Martorano, 2006; Mickler, 2017) suggests that committees are more autonomous and influential when their remits match those of the government ministries they are tasked with overseeing because these committees' members do not have to share oversight responsibilities and compete with other committees for attention and influence over the ministry's actions. Moreover, members of committees with overlapping remits do not have to share credit with other committees for particularistic goods delivered to constituents - even if the representative did not have any actual impact on delivering the goods in question (e.g. goods distributed by bureaucratic formulae). This increased potential for credit claiming makes these committees more attractive for representatives pursuing their re-election interests through representation of constituents' preferences. This suggests the impact of constituency preferences 
on committee assignments may be stronger on committees whose remits overlap with the relevant ministry than committees whose remits do not overlap.

H3: The effects of constituency preferences will be strongest when a committee's remit matches the jurisdiction of the government ministry for which it is tasked to provide oversight.

Moreover, committees may be more attractive to representatives if their remits are more focused than if their jurisdictions are overly expansive. When committees have jurisdiction over several different policy areas, representatives of multiple interests must compete with each other for the committee's time. When committees' remits centre on one narrow topic, this means the committee's hearings and committee votes will be focused on the topic of interest for members. This greater focus, in turn, increases the incentives for representatives to seek assignment to these committees, as credit-claiming and position-taking efforts on one policy issue do not have to compete with other issues for representatives' time and action. For example, a committee whose sole focus is agriculture will only deal with agricultural issues, giving its members many opportunities for position-taking and credit claiming. When a committee's jurisdiction includes agriculture and other natural resources like mining, some of its time will be focused on issues such as mining and resource extraction. This reduces the chances for members representing agricultural districts to represent their constituents' interests on agricultural issues because these issues have to compete with other issues for the committee's time.

H4: The effects of constituency preferences will be weaker when the committee's remit includes several issue areas under its jurisdiction than when the committee's mission is specifically 
focused on agricultural issues.

Finally, the effects of constituency preferences on committee selection may be conditional on the regional/national consequences of individual representatives' personal voteseeking for the party brand. Specifically, the impact of constituency preferences on individual representatives' selection to committees may weaken as the share of the total population of a country/region sharing those preferences increases. Consistent with cartel theory (Cox and McCubbins, 1993, pp.191-199), which acknowledges that parties may be willing to tolerate personal vote-seeking by their members when the potential impact on the party's agenda is low, party leaders may be less willing to select members to committees when those members' personal vote-seeking behaviour has greater consequences for the party brand among a large group of voters. When the share of the overall population concerned with a particular issue is low, the potential damage of personal vote-seeking among voters in particular constituencies through committee work is similarly low; when the share of the overall population concerned with that issue is high - meaning that the total number of voters evaluating the party brand is also high - the actions of representatives seeking re-election have greater consequences for the party brand. As a result, we also test the following hypothesis:

H5: The effects of constituency preferences will be weaker in countries/regions with more constituents belonging to the particularistic group in question.

\section{Research design}

To test these hypotheses, we collected a data set consisting of individual representatives 
from a wide range of legislatures around the world at both the national and devolved regional levels for which appropriate data were available. The chief factor limiting data collection was the availability of district-level census data allowing us to measure constituency preferences. This reliance on district-level census data ultimately limits our data set to long-established democracies, most of which are designed based on Westminster traditions. That said, our data set does include a variety of legislatures from Western Europe - including the elected legislatures in the most populous countries - as well as two prominent Latin American legislatures. To simplify the data collection process, we examined the most recent election in each country.

To facilitate comparisons across legislatures, the analysis below focuses on committees dealing with agricultural issues. Committees dealing with agricultural issues have several important advantages making them ideal for examining the effects of constituency preferences on committee selection. First, committees dealing with agriculture have been some of the most likely in previous research to provide evidence of constituency preference effects on committee selection in line with distributive theory. If distributive theory is to be of any use explaining committee selection cross-nationally, then the effects of constituency preferences on committee selection should be present on committees dealing with agriculture. In this way, focusing on committees dealing with agriculture presents a critical test of distributive theory. If constituency preference effects do not emerge when examining these committees, then it would be doubtful that distributive theory is of much use in the cross-national study of selection to other committees. Second, and most important, is that focusing on committees dealing with agriculture facilitates precise measurement of constituency preferences (discussed in the paragraph below). The resulting list of legislatures and committees dealing with agricultural issues appears in Table 
1. ${ }^{1}$ Our dependent variable is a binary indicator of whether the representative was assigned to the agricultural committee.

To measure representatives' constituency preferences pressuring them to seek selection to committees allowing them to pursue personal vote-seeking strategies, we follow the approach of Adler and Lapinski (1997; Adler, 2000). This approach measures constituency preferences using district-level census data taken from each country's census or national statistics office. To measure constituency preferences putting pressure on representatives to seek selection to committees dealing with agriculture issues, we measure the proportion of representatives' constituent workforces employed in agriculture-related occupations according to the electoral tier in which representatives were elected. ${ }^{2}$ In most cases, this is the single- or multi-member district in which representatives were elected. In the case of mixed-member proportional electoral systems like that used to elect members of the German Bundestag, where some members are elected in list tiers representing national constituencies, we treat the nationwide proportion employed in agriculture-related occupations as the measure of constituency preferences.

\footnotetext{
${ }^{1}$ In the case of the Canadian House of Commons, members representing constituencies with more people employed in fishing industries may also have sought appointment to the Fisheries and Oceans Committee. Including membership on this committee does not change the results presented here.

${ }^{2}$ Two interesting cases to note are the Mexican Cámara de Diputados and the Dutch Tweede Kamer. In the Mexican Cámara de Diputados, data were only available at the state (not district) level. Moreover, representatives in the present term are prevented from seeking re-election, which reduces the incentives for representatives to personally seek selection to committees. In the Netherlands, this variable is measured as the percentage of the provincial population employed in agriculture-related occupations. This is because while members of the Tweede Kamer are elected in a single nationwide constituency, candidates are selected according to province and are viewed as representatives of their provinces (Lattner and McGann, 2005). Recognizing the difference in definition of constituency, as well as the difference in the denominator of this variable, we re-estimated each model by dropping the Netherlands in order to ensure the robustness of the findings. The results dropping the Netherlands, the Cámara de Diputados, or both are substantively equivalent to those presented here.
} 
Distributive theory would predict that representatives from constituencies with more people employed in agriculture would face greater pressures from constituents to seek assignment to agriculture committees to represent their distributive concerns and seek particularistic benefits from the committees.

To account for the possibility that the impact of constituency preferences may be specific to the context of each legislature, we examine a second, country-/region-specific measure of constituency preferences pressuring representatives to seek selection to agriculture committees. This second measure re-scales the raw data into context-specific measures of constituency preferences by dividing the proportion employed in agriculture-related occupations by its country/region-specific maximum value. This leaves a scale ranging from zero (no-one in the constituency is employed in agriculture-related occupations) to one (the highest constituency proportion employed in agriculture-related occupations observed in the legislature). The resulting measure allows us to test the possibility that representatives with the highest proportions of constituents employed in agriculture-related occupations in their legislature will have probabilities of being selected to committee equal to those with the highest proportions of agricultural employment in other legislatures.

To test hypotheses 2-6, we include separate variables measuring each moderating variable and interact these variables with constituency preferences. Details for the moderating variables associated with each hypothesis are presented below:

H2: a series of indicators measuring different electoral systems with varying theorised degrees of personal vote incentives. We include separate indicators for representatives elected in singlemember district plurality systems (SMDP Systems), single-transferable or alternative vote 
systems (STV/AV Systems), two-round majority systems (Two-Round Majority), and open-list proportional representation systems (Open-List PR). In each case, representatives elected in a different electoral system from the one listed are treated as the baseline.

H3: an indicator - Ministry Overlap - coded 1 for legislatures where the agriculture committee's remit overlaps with the jurisdiction of the ministry it oversees, and 0 otherwise.

H4: an indicator - General Remit - coded 1 for legislatures where the agriculture committee's remit includes issue areas beyond agriculture and agriculture-related issues, and 0 otherwise.

H5: a variable - Total Agricultural Employment - measuring the percentage of the workforce in each legislature's aggregate population employed in agriculture-related occupations. Data for this variable are taken from each country's census or national statistics office.

Summary information for each variable, broken down by legislature, is presented in Table 1.

In addition to these variables, we also examine several control variables. To account for differences in the baseline probabilities of being selected to agriculture committees resulting from differences in the size of committees dealing with agriculture issues relative to the total number of legislators (i.e. the larger the size of the committee relative to the number of seats in the legislature, the greater the chances of being selected to the committee), we include a variable measuring the number of seats on the committee divided by the total number of legislators. Because previous research has shown - in keeping with informational theory - that representatives with subject expertise are more likely to be selected to committees dealing with 
related issues than non-specialists (Mickler, 2018a, 2018b), we include a variable coded 1 for representatives with career or family backgrounds in agriculture-related occupations, and 0 otherwise. To account for the potential that female representatives may be less likely to be selected to committee than their male counterparts seen in previous research (Pansardi and Vercesi, 2017), we include an indicator for female representatives, as well as an interaction with the variable measuring constituency preferences. To account for differences between national and devolved legislatures in terms of their potential to shape agricultural policy - which, in turn, might affect the impact of constituency preferences on representatives' desire to seek committee assignments - we include a dummy variable distinguishing devolved and national legislatures and interact this with constituency preferences. Similarly, we also include a dummy variable distinguishing upper and lower chambers and interact this with constituency preferences.

To estimate the impact of constituency preferences on selection to agricultural committees, we use multilevel logistic regression. This allows us to account for the fact that appointments to committee are nested in different countries. We estimate a total of four models. Models 1 and 3 test $\mathrm{H} 1$ by estimating the effects of the variables measuring the raw and countryspecific measures of constituency preferences, respectively, on committee selection - net of the control variables. Models 2 and 4, using these same measures of constituency preferences, include the moderating variables and interactions associated with $\mathrm{H} 2-\mathrm{H} 5$.

\section{Results}

Parameter estimates for each model are presented in Table 2. The results from each model provide considerable support for $\mathrm{H} 1$. Whether constituency preferences are measured as a raw proportion or as a legislature-specific value, the coefficients measuring constituency 
preferences are positive, suggesting that representatives with more constituents employed in agriculture-related occupations are more likely to be selected to committees dealing with agriculture-related issues. The small p-values associated with each coefficient suggest we can confidently reject the null hypothesis in favour of $\mathrm{H} 1$.

This finding holds despite the fact that several variables associated with rival alternative explanations also reach statistical significance. For instance, and in keeping with previous research (e.g. Mickler, 2018a, 2018b), subject-specific expertise appears to increase the probability that representatives will be selected to committees, as implied by the significant positive coefficients for the variable measuring representatives with agriculture-related employment experience. Moreover, the impact of constituency preferences appears weaker among female representatives, as well as representatives in devolved legislatures and upper chambers (at least according to models 3 and 4), as implied by the negative coefficients for the interactions between these variables and the measures of constituency preferences. Despite these differences in the effects of constituency preferences, the results in each model suggest the general pattern of constituency preferences influencing selection to committees holds across all four models.

To visualise the estimated effects of constituency preferences on selection to committees dealing with agriculture issues, Figure 1 presents the predicted probabilities of being selected to committee for both male and female representatives using the results from models 2 and 4 (holding all other variables at their median values). As the proportion of constituents employed in agriculture-related occupations increases, the probability of being selected to committees dealing with agriculture issues increases. While the predicted probabilities are lower for female than male representatives in constituencies with more people employed in agriculture-related 
occupations, the fact is that the probability increases significantly for both. Whether using the raw proportion of constituents employed in agriculture-related occupations or the contextspecific measure of constituency preferences, moving from the minimum to the maximum values of constituency preferences results in increases of more than 20 percentage points (increasing from probabilities of seven per cent to 30 per cent or more) in the probabilities of being selected to agriculture-related committees among male representatives. Although the results suggest concerning gender-based differences in the probabilities of being selected to committees, higher values of constituency preferences are associated with higher probabilities of female representatives being selected to agriculture-related committees, with the probability of being selected increasing from roughly 10 per cent to more than 20 per cent when moving from the lowest to the highest values of both constituency preference measures.

While H1 finds strong support, the results provide little evidence to support the hypotheses suggesting that the effects of constituency preferences are dependent on different institutional settings. The estimated interactions between constituency preferences on the one hand and the various electoral systems examined here fail to yield significant differences in the estimated effects of constituency preferences on committee selection - as demonstrated by the statistically insignificant coefficients for the interaction terms. The results similarly fail to support the hypotheses regarding the impact of committee remits - both the degree to which committee remits overlap with relevant ministries (H3) and the specificity of committees' agricultural remits (H4) - on the relationship between constituency preferences and selection to committees dealing with agricultural issues.

The one variable consistently associated with differences in the impact of constituency preferences on committee selection, however, is the variable measuring the proportion of 
constituents in the territory employed in agriculture-related occupations. As implied by the coefficients measuring the interaction between constituency-level employment and the proportion of constituents in the country/region employed in agriculture-related occupations, the effect of constituency preferences declines as country-/regional-level employment in agriculture increases. This can be seen more clearly in Figure 2, which presents the estimated marginal effects of constituency preferences across the range of Total Agricultural Employment; all other variables are held at their median values. With both measures of constituency preferences, we see that the estimated effects of constituency preferences are strongest at the lowest levels of region-/nationwide agricultural employment. These effects decrease as total agricultural employment increases, becoming statistically indistinguishable from zero at the highest levels of nationwide/regional agricultural employment. In keeping with $\mathrm{H} 5$, these results suggest that when the total share of voters affected by policy is low (i.e. from cartel theory's perspective, the potential damage to representatives' party brands is low), constituency preferences have their strongest effects on committee selection; when the total share of voters affected by policy is high (i.e. the potential damage to the party brand is high), the impact of constituency preferences on committee selection is weakest, suggesting that party leaders may be less willing to select representatives to committees in these contexts. Though the magnitude of the estimated effects of constituency preferences on committee selection are considerably weaker in model 4 than in model 2, the fact remains that constituency preferences in both models are estimated to weaken in contexts of high agricultural employment.

\section{Conclusion}

This paper has analysed the impact of constituency preferences on committee selection - 
and the impact of variables that could potentially moderate the effects of constituency preferences - in a broad range of legislatures around the world. Two sets of conclusions can be drawn from the findings presented above. First, the results presented here provide evidence to suggest that constituency preferences impact committee selection in a wide range of legislatures. Examining selection to committees with clear particularistic interests and associated with distributive concerns - committees tasked with handling legislation regarding agricultural issues - across a range of legislatures, the results show that representatives from districts with more people employed in agriculture-related occupations are more likely to be selected to these committees than representatives from districts in which smaller shares of constituents are employed in agriculture. Rather than being limited to the handful of legislatures in which the impact of constituency preferences on committee selection has previously been studied, the findings presented here show that constituency effects can be seen on committee selection in legislatures around the world. This provides considerable support for the notion that distributive theory has important implications for the operation of legislatures and the behaviour of members cross-nationally.

Second, the analysis examined whether the impact of constituency preferences on selection to committees is conditioned by factors specific to each legislature. We examined the potential for different electoral systems to condition the effects of constituency preferences on committee selection, as well as hypotheses regarding the potential for differences in the remit of committees to condition the impact of constituency preferences. The analysis, however, found little evidence to suggest that these institutional factors conditioned the effects of constituency preferences in a clear, systematic way. Instead, the analysis suggested the effects of constituency preferences are conditioned by the degree to which personal vote-seeking threatens 
representatives' party brands: while the estimated effects of constituency preferences on committee selection are strong in contexts where the share of the population concerned with a particularistic issue is low, in contexts where the share of the population concerned with a particularistic issue is high (and, thus, the potential threat to parties' brands are higher), the effects of constituency preferences on committee selection are weaker. While more research examining cross-national variation in the impact of constituency preferences on committee selection is needed - particularly to understand why institutional factors do not have the impact predicted by previous literature - the fact constituency preferences continue to impact selection to committees in the legislatures examined here even after accounting for several potentially confounding factors suggests that constituency effects on committee selection may be part of a cross-national phenomenon, and that distributive theory may travel well to legislatures outside the US.

Though this study presents several interesting findings, there remains much more work to be done in the study of committee selection from a distributive perspective. For one, because this study was limited to committees dealing with agricultural issues, future research will need to expand the focus to examine the effects of constituency preferences on committees dealing with other issues. Though this limited focus was necessary to simplify the tasks of data collection and comparability across legislatures, such limitation necessitates that future research expand the focus to committees dealing with other types of issues to ensure that the results presented above are part of a broader phenomenon of constituency preferences impacting committee selection and one that is not limited to agricultural issues alone.

Moreover, there is need in future research to examine which legislatures possess committees focused specifically on particularistic issues and why institutions are structured in 
such a way (while others are not). For instance, future research is needed to understand why some legislatures feature committees offering opportunities for representatives to pursue distributive policies (like committees devoted to representing particularistic agricultural issues) whose remits are clear and overlapping with government ministries whilst others do not. It may be possible that pressures from constituents lead parties and/or individual representatives to prefer and design institutions that allow for the expression of these particularistic interests. Such a finding drawing from evidence collected from a wide body of legislatures would help to refine and elaborate on distributive theory. 
Table 1 Characteristics of Each Legislature and Its Members

\begin{tabular}{|c|c|c|c|c|c|c|}
\hline \multirow[b]{2}{*}{ Legislatures/Committee (Year) } & \multicolumn{5}{|c|}{ Variables } & \multirow[b]{2}{*}{$\begin{array}{l}\text { Total } \\
\text { Potential }^{6}\end{array}$} \\
\hline & Preferences ${ }^{1}$ & $\begin{array}{l}\text { Personal Vote } \\
\text { Systems }^{2}\end{array}$ & $\begin{array}{l}\text { District } \\
\text { Magnitude }\end{array}$ & $\begin{array}{l}\text { Ministry } \\
\text { Overlap }\end{array}$ & $\begin{array}{l}\text { General } \\
\text { Remit }{ }^{5}\end{array}$ & \\
\hline $\begin{array}{l}\text { Assemblée Nationale (France)/Economic } \\
\text { Affairs (2012) }\end{array}$ & $1.06(1.18)$ & 1 & $1-1$ & 0 & 1 & 1.07 \\
\hline $\begin{array}{l}\text { Assemblée Nationale (Québec)/ } \\
\text { Agriculture, Fisheries, Energy and } \\
\text { Natural Resources (2014) }\end{array}$ & $2.27(2.91)$ & 1 & $1-1$ & 0 & 1 & 1.41 \\
\hline $\begin{array}{l}\text { Bundestag/Food and Agriculture } \\
\text { (2013) }\end{array}$ & $1.02(0.74)$ & $0 / 1$ & $1-299$ & 1 & 0 & 1.09 \\
\hline $\begin{array}{l}\text { Cámara de Diputados (Mexico)/Agriculture } \\
\text { and Irrigation Systems (2015) }\end{array}$ & $10.85(7.39)$ & $0 / 1$ & $1-200$ & 0 & 0 & 10.56 \\
\hline $\begin{array}{l}\text { Cámara de Senadores (Mexico)/Agriculture } \\
\text { and Livestock (2012) }\end{array}$ & $11.16(7.14)$ & 0 & $3-32$ & 0 & 0 & 10.56 \\
\hline $\begin{array}{l}\text { Câmara dos Deputados (Brazil)/Agriculture } \\
\text { Livestock, Food Supply, and Rural } \\
\text { Development (2014) }\end{array}$ & $14.49(7.66)$ & 0 & $8-70$ & 0 & 1 & 13.11 \\
\hline $\begin{array}{l}\text { Camera dei Deputati (Italy)/Agriculture } \\
\text { (2013) }\end{array}$ & $3.96(2.54)$ & 0 & $1-45$ & 0 & 0 & 3.60 \\
\hline $\begin{array}{l}\text { Congreso de los Diputados (Spain)/ } \\
\text { Agriculture, Food, and the Environment } \\
\text { (2016) }\end{array}$ & $5.33(5.47)$ & 0 & $1-36$ & 1 & 1 & 5.30 \\
\hline $\begin{array}{l}\text { Council of States (Switzerland)/Economic } \\
\text { Affairs and Taxation (2015) }\end{array}$ & $4.58(2.62)$ & $0 / 1$ & $1-2$ & 0 & 1 & 2.44 \\
\hline $\begin{array}{l}\text { Dáil Éireann/ Agriculture, Food, and the } \\
\text { Marine (2011) }\end{array}$ & $5.18(4.25)$ & 1 & $3-5$ & 1 & 0 & 4.22 \\
\hline
\end{tabular}


House of Commons (Canada)/Agriculture and Agri-Food (2011)

House of Commons (United Kingdom)/ Environment, Food, and Rural Affairs (2015)

$1.08(1.59) \quad 1$

House of Representatives (Australia)/ Agriculture and Industry (2013)

House of Representatives (New Zealand)/ Primary Production (2014)

$$
6.38(5.33) \quad 0 / 1
$$

Legislative Assembly (British Columbia)/ Public Accounts (2013)

National Assembly for Wales/Environment and Sustainability (2011)

National Council (Switzerland)/Economic Affairs and Taxation (2015)

Northern Ireland Assembly/Agriculture and Rural Development (2011)

Parliament of South Australia/Environment, Resources, and Development; Natural Resources (2010)

Parliament of Victoria/Environment, Natural Resources, and Regional Development (2010)

Parliament of Western Australia/Economics and Industry (2013) 
Scottish Parliament/Rural Affairs, Climate

Change, and the Environment (2011)

Senado Federal (Brazil)/Agriculture, Livestock, Food Supply, and Rural Development (2014)

Senate (Australia)/Rural and Regional Affairs and Transport Legislation (2013) 1.35 (0.47) $\quad 1$

Senato della Repubblica (Italy)/Agriculture and Food Production (2013)

Storting (Norway)/Business and Industry (2013)

Tweede Kamer (Netherlands)/Economic Affairs (2012)

Notes: ${ }^{1}$ The values in this column reflect the mean (standard deviation) of the variable measuring the percentage (for the sake of presentation in this table) employed in agriculture-related occupations in members' constituencies. ${ }^{2} 1$ for legislatures in which members are elected under single-member district, STV, AV, two-round majority, or open-list PR electoral systems, and 0 otherwise (" $0 / 1$ " reflects legislatures elected in part by both types of electoral systems). ${ }^{3}$ Values represents the minimum and maximum values of district magnitude. ${ }^{4} 1$ for legislatures in which committees' jurisdictions overlap with those of the ministries they oversee, and 0 otherwise. ${ }^{5} 1$ for legislatures in which committees' jurisdictions are general, and 0 for committees with specific jurisdictions focused on distributive issues. ${ }^{6}$ Entries in the "Total Potential" column are the percentages (again, for presentation purposes) of the total population in each territory employed in agriculture-related occupations. 
Table 2 Multilevel Logistic Regression Estimates of Selection to Agricultural Committees

\begin{tabular}{|c|c|c|c|c|}
\hline \multirow[b]{2}{*}{ Variables } & \multicolumn{4}{|c|}{ Model } \\
\hline & 1 & 2 & 3 & 4 \\
\hline Constituency Preferences & $6.20 * *$ & $14.25 * *$ & & \\
\hline Country-Specific Preferences & & & $1.91 * *$ & $2.30 * *$ \\
\hline SMDP Systems & & -0.20 & & -0.25 \\
\hline STV/AV Systems & & -0.28 & & -0.25 \\
\hline Two-Round Majority & & 0.32 & & $0.80^{*}$ \\
\hline Open-List PR & & 0.50 & & 0.88 \\
\hline Ministry Overlap & & 0.04 & & 0.10 \\
\hline General Remit & & -0.24 & & -0.36 \\
\hline Total Agricultural Employment & & -5.06 & & -1.30 \\
\hline Preferences $\times$ SMDP & & 1.81 & & 0.38 \\
\hline Preferences $\times$ STV $/$ AV & & 2.41 & & -0.54 \\
\hline Preferences $\times$ Two-Round & & 4.30 & & -0.55 \\
\hline Preferences $\times$ Open-List PR & & -16.64 & & -2.57 \\
\hline Preferences $\times$ Overlap & & 0.04 & & 0.70 \\
\hline Preferences $\times$ Remit & & 2.83 & & 0.50 \\
\hline Preferences $\times$ Total Potential & & $-109.11 * *$ & & $-14.10^{*}$ \\
\hline Subject Expertise & $1.56^{* *}$ & $1.54 * *$ & $1.51 * *$ & $1.53 * *$ \\
\hline Committee Seats/Total Seats & $6.08 * *$ & $7.13 * *$ & $5.79 * *$ & $6.01 * *$ \\
\hline Female Representatives & 0.18 & $0.24 *$ & $0.32 *$ & $0.36^{*}$ \\
\hline Females $\times$ Preferences & -3.02 & $-4.18^{*}$ & $-0.90 *$ & $-1.03 * *$ \\
\hline Devolved Legislature & 0.00 & 0.17 & 0.23 & $0.60^{*}$ \\
\hline Devolved $\times$ Preferences & 3.98 & -6.58 & -0.36 & $-1.17^{*}$ \\
\hline Upper Chambers & 0.09 & -0.03 & 0.35 & 0.29 \\
\hline Upper Chambers $\times$ Preferences & $-4.18^{*}$ & -1.86 & $-1.41 *$ & $-1.15^{*}$ \\
\hline Constant & $-3.33 * *$ & $-3.17 * *$ & $-3.58 * *$ & $-3.41 * *$ \\
\hline$\sigma^{2}$ Constant & 0.27 & 0.14 & 0.19 & 0.08 \\
\hline Wald $\chi^{2}$ & $250.13 * *$ & $305.77 * *$ & $293.41 * *$ & $356.04 * *$ \\
\hline $\mathrm{BIC}$ & 4482.89 & 4566.74 & 4446.50 & 4539.91 \\
\hline n (Legislatures) & 29 & 29 & 29 & 29 \\
\hline n (Total) & 6983 & 6983 & 6983 & 6983 \\
\hline
\end{tabular}

$* \mathrm{p}<0.05,{ }^{* *} \mathrm{p}<0.005$, two-tailed tests. Entries are multilevel logistic regression coefficients. "BIC" = Bayesian Information Criterion. 
Figure 1 Predicted Probabilities of Selection to Committees Dealing with Agriculture Issues
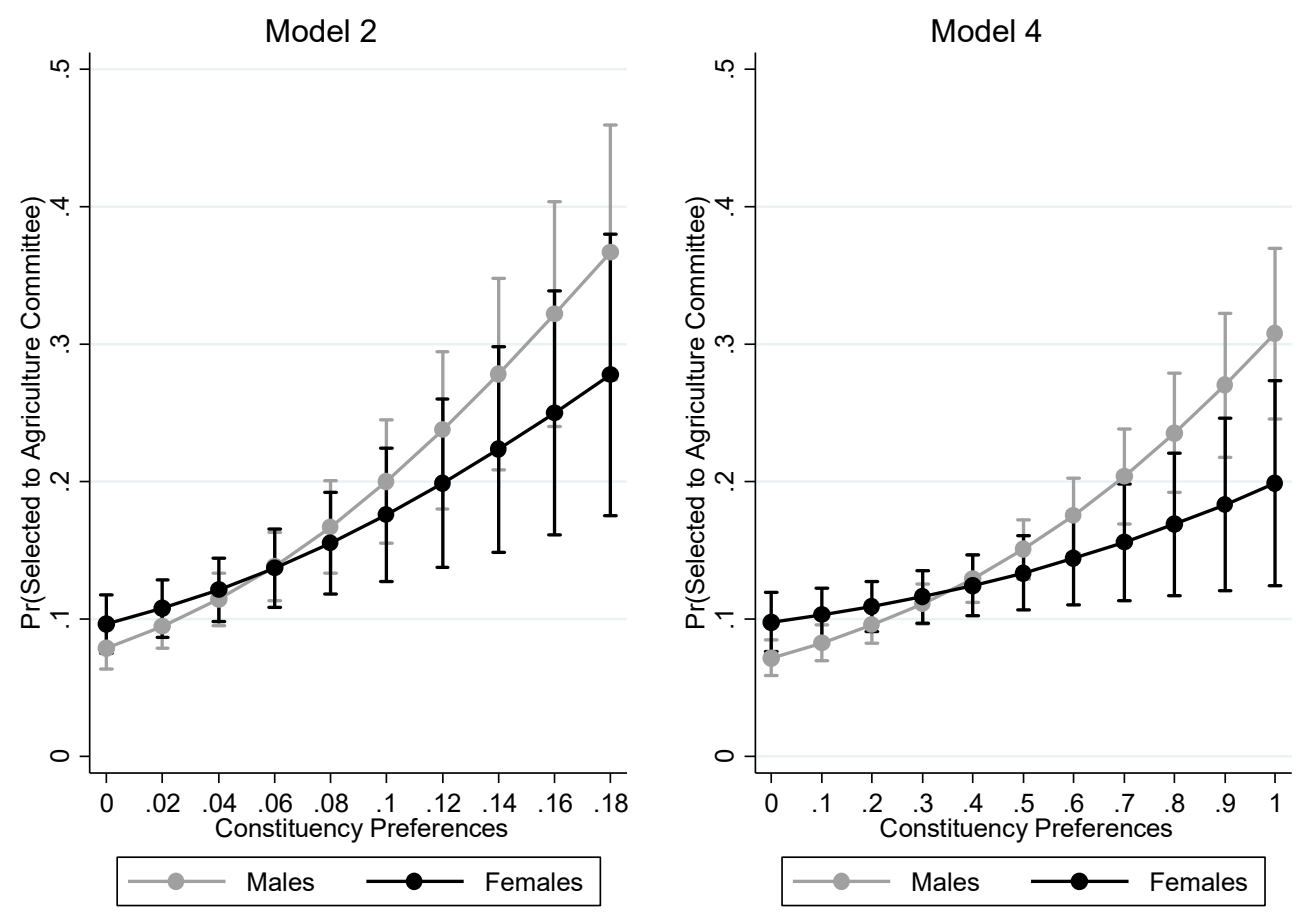

Note: dots represent the predicted probabilities of being selected to committees dealing with agricultural issues across the range of each measure of constituency preferences, while bars represent $95 \%$ confidence intervals. 
Figure 2 Marginal Effects of Constituency Preferences on Selection to Agriculture-Related Committees, Conditional on Total Agricultural Employment
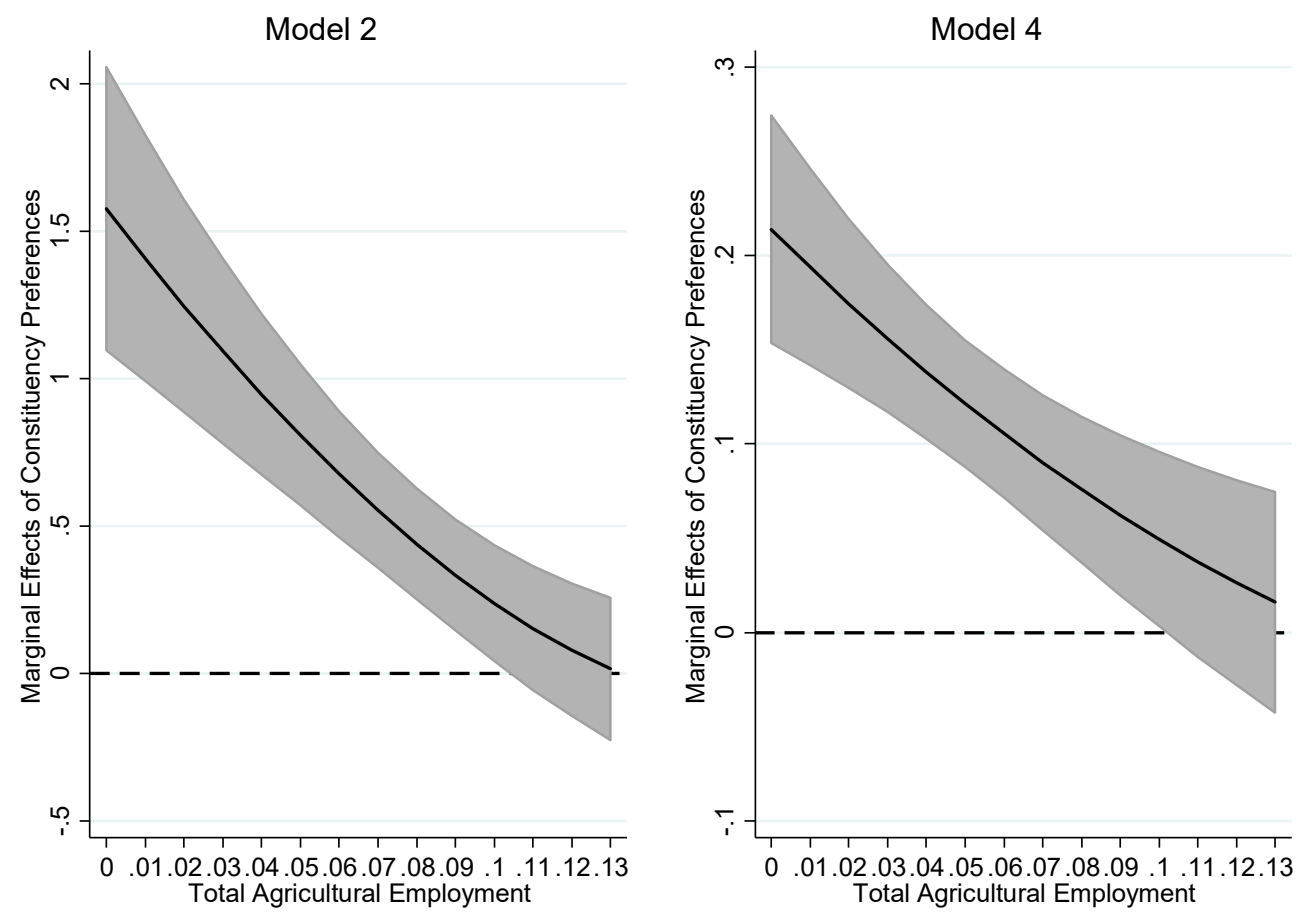

Note: solid black lines are the predicted marginal effects of constituency preferences on the probabilities of being selected to committees dealing with agricultural issues, conditional on the variable measuring the percentage of the country/region employed in agriculture-related occupations, while the areas shaded in grey represent $95 \%$ confidence intervals. 


\section{References}

Adler, E.S. (2000) 'Constituency Characteristics and the 'Guardian' Model of Appropriations Subcommittees, 1959-1998', American Journal of Political Science, 44(1), 104-114. Adler, E.S., and Lapinski, J.S. (1997) 'Demand-Side Theory and Congressional Committee Composition: A Constituency Characteristics Approach', American Journal of Political Science, 41(3), 895-918.

André, A., Freire, A. and Papp, Z. (2014) ‘Electoral Rules and Legislators’ Personal VoteSeeking' In: Deschouwer, K. and Depauw, S. (eds.) Representing the People. A Survey Among Members of Statewide and Substate Parliaments, Oxford: Oxford University Press pp.87-109.

André, A., Depauw, S. and Martin, S. (2015) 'Electoral Systems and Legislators' Constituency Effort: The Mediating Effect of Electoral Vulnerability’, Comparative Political Studies, 48(1), 47-56.

André, A., Depauw, S. and Martin, S. (2016a) “"Trust Is Good, Control Is Better” Multiparty Government and Legislative Organization', Political Research Quarterly, 69(1), 108120.

André, A., Depauw, S. and Martin, S. (2016b) 'The classification of electoral systems: Bringing legislators back in', Electoral Studies, 42, 42-53.

Cain, B.E., Ferejohn, J. and Fiorina, M. (1987) The Personal Vote: Constituency Service and Electoral Independence. Cambridge: Harvard University Press.

Carey, J.M. and Shugart, M.S. (1995) 'Incentives to cultivate a personal vote: A rank ordering of electoral formulas', Electoral Studies, 14(4), 417-439.

Carsey, T.M. and Rundquist, B. (1999) 'Party and committee in distributive politics: Evidence from defense spending', The Journal of Politics, 61(4), 1156-1169. Ciftci, S., Forrest, W. and Tekin, Y. (2008) 'Committee Assignments in a Nascent Party 
System: The Case of the Turkish Grand National Assembly', International Political Science Review, 29(3), 303-324.

Cox, G.W. and McCubbins, M.D. (1993) Legislative Leviathan: Party Government in the House. Berkeley: University of California Press.

Fujimura, N. (2012) 'Electoral incentives, party discipline, and legislative organization: manipulating legislative committees to win elections and maintain party unity', European Political Science Review, 4(2), 147-175.

Gilligan, T.W. and Krehbiel, K. (1990) 'Organization of Informative Committees by a Rational Legislature', American Journal of Political Science, 34(2), 531-564.

Groseclose, T. (1994) 'Testing Committee Composition Hypotheses for the U.S. Congress', Journal of Politics, 56(2), 440-458.

Hansen, M.E. (2010) 'Committee Assignment Politics in the Danish Folketing', Scandinavian Political Studies, 33(4), 381-401.

Heitshusen, V., Young, G. and Wood, D.M. (2005) 'Electoral Context and MP Constituency Focus in Australia, Canada, Ireland, New Zealand, and the United Kingdom', American Journal of Political Science, 49(1), 32-45.

Krehbiel, K. (1990) ‘Are Congressional Committees Composed of Preference Outliers?', American Political Science Review, 84(1), 149-163.

Krehbiel, K. (1991) Information and Legislative Organization. Ann Arbor: University of Michigan Press.

Latner, M. and McGann, A. (2005) 'Geographical representation under proportional representation: The cases of Israel and the Netherlands', Electoral Studies, 24(4), 709734.

Londregan, J. and Snyder, J.M. (1994) ‘Comparing Committee and Floor Preferences', Legislative Studies Quarterly, 19(2), 233-266. 
Martin S. and Mickler, T. (2018) 'Committee Assignments: Theories, Causes and Consequences', Parliamentary Affairs.

Mayhew, D.R. (1974) Congress: The Electoral Connection. New Haven: Yale University Press.

Mickler, T.A. (2017) 'Committee autonomy in parliamentary systems-coalition logic or congressional rationales?', The Journal of Legislative Studies, 23(3), 367-391.

Mickler, T.A. (2018a) 'Not so random after all?-revisiting committee assignments in Dáil Éireann', Irish Political Studies, 33(1), 112-135.

Mickler, T.A. (2018b) 'Who gets what and why? Committee assignments in the German Bundestag', West European Politics, 41(2), 517-539.

Overby, L.M. and Kazee, T.A. (2000) 'Outlying Committees in the Statehouse: An Examination of the Prevalence of Committee Outliers in State Legislatures', Journal of Politics, 62(3), 701-728.

Overby, L.M., Kazee, T.A. and Prince, D.W. (2004) 'Committee Outliers in State Legislatures', Legislative Studies Quarterly, 29(1), 81-107.

Pansardi, P. and Vercesi, M. (2017) 'Party Gate-Keeping and Women's Appointment to Parliamentary Committees: Evidence from the Italian Case', Parliamentary Affairs, 70(1), 62-83.

Prince, D.W. and Overby, L.M. (2005) 'Legislative Organization Theory and Committee Preference Outliers', State Politics and Policy Quarterly, 5(1), 68-87.

Raymond, C. and Holt, J. (2014) 'Due North? Do American Theories of Legislative Committees Apply to Canada?', The Journal of Legislative Studies, 20(2), 174-192. 
Raymond, C. and Holt, J. (2017) 'Constituency Pressures on Committee Selection: Evidence from the Northern Ireland Assembly and Dáil Éireann', Parliamentary Affairs, Advance Access published on 20 February 2017, DOI: 10.1093/pa/gsx002.

Shepsle, K.A. (1978) The Giant Jigsaw Puzzle. Chicago, IL: University of Chicago Press.

Shepsle, K.A. and Weingast, B.R. (1981) 'Political preferences for the pork barrel: A generalization', American Journal of Political Science, 25(1), 96-111.

Shepsle, K.A. and Weingast B.R. (1995) 'Positive Theories of Congressional Institutions' In: Shepsle, K.A. and Weingast, B.R. (eds.) Positive Theories of Congressional Institutions. Ann Arbor: University of Michigan Press pp.5-36.

Sprague, M. (2008) 'The effects of measurement and methods decisions on committee preference outlier results', Political Research Quarterly, 61(2), 309-318.

Stratmann, T. and Baur, M. (2002) 'Plurality Rule, Proportional Representation, and the German Bundestag: How Incentives to Pork-Barrel Differ across Electoral Systems', American Journal of Political Science, 46(3), 506-514.

Weingast, B.R. and Marshall, W. (1988) 'The Industrial Organization of Congress', Journal of Political Economy, 96(1), 132-163.

Yordanova, N. (2009) 'The Rationale Behind Committee Assignment in the European Parliament: Distributive, Informational and Partisan Perspectives', European Union Politics, 10(2), 253-80. 